\title{
Toward Web 5.0 in Italian Regional Destination Marketing
}

\author{
Mariapina Trunfio*, Maria Della Lucia**
}

\begin{abstract}
The exploitation of Web opportunities for market destinations fosters the cocreating destination value through engaging diverse stakeholders in social communication and knowledge sharing. Leveraging the body of destination management literature focused on Web 2.0, we introduce the debate on the Web's evolution from 2.0 to 5.0, identifying best practices in digital marketing and the use of innovative Web tools in four Italian regional destinations. DMOs have largely adopted Web 2.0 tools fostering strong forms of stakeholder engagement in destination marketing and implementing Web 3.0 and Web 4.0 tools to support innovative forms of destination marketing. Of the Web 2.0 applications, social media marketing via Facebook seems to play the biggest role in engaging potential tourists, but performances differ among destinations, depending on the extent of community participation in content generation and the speed of reaction to content.
\end{abstract}

Keywords: Evolutionary Web; Web of Communication; Destination Marketing; Tourism Experience Co-Creation; Global Tourism; Italian Regional Destinations

\section{Reshaping Spaces and Boundaries}

The digital economy (Rifkin, 2011) has reshaped the competitive, cognitive and social spaces of cities, regions and countries around the world by introducing new destination models in which marketing strategies and experiences are co-created through stakeholder contributions, thus defining a participatory approach to territorial development. Technology-led interactions between and within destination actors and tourists in virtual communities (Buhalis \& Law, 2008) enable knowledge-based processes powered on one hand by user participation and openness, and on the other by network activities and stakeholder engagement in destination management (Cabiddu, De Carlo, \& Piccoli, 2014; Funilkul \& Chutimaskul, 2009; Munar, 2012). This technology-led knowledge sharing and creation (Racherla, Hu, \& Hyun, 2008) provides opportunities for smart destination development (Trunfio, Go, \& Ferretti, 2012) in which the co-creation of advanced products and services involving the whole tourist and destination supply chain goes

\footnotetext{
*Associate Professor of Tourism and Business Management, University of Naples "Parthenope" (trunfio@uniparthenope.it)

** Associate Professor of Tourism and Business Management, University of Trento (maria.dellalucia@unitn.it)
}

Edited by: ISTEI - University of Milan-Bicocca

ISSN: 1593-0319

Trunfio, M., \& Della Lucia, M. (2016). Toward Web 5.0 in Italian Regional Destionation Marketing, Symphonya. Emerging Issues in Management (symphonya.unimib.it), 2, 60-75. 
in tandem with social innovations (Chen \& Choi, 2004). This enables new ways of living, producing, consuming and experiencing, affecting both how local people interact and their relationship with visitors. The transition of the digital world towards evolutionary Web tools, shifting from the Web of Communication (Web 2.0) towards the Web of Thought (Web 5.0), fosters these processes and enhances their complexity. There is a clear need for further empirical research in this domain by both academics and practitioners. By the former, to strengthen the theoretical background, by the latter, to enable implementing the new levers of destination competitive advantage. This paper is intended to contribute to the debate on the evolving Web tools by identifying best practices in the use of innovative Web tools to enhance the competitiveness of Italian regional destinations. Italy is one of the world's top tourist destinations, ranking 5th in terms of international tourist arrivals and 7th in terms of tourism receipts (UNWTO, 2016). Travel \& Tourism accounts for $10.2 \%$ of national GDP (WTTC, 2016). The relationship between digitalisation, stakeholder engagement and destination value co-creation is currently being debated in the participatory planning process of the National Strategy for Tourism (2016-2021) (http://www.pst.beniculturali.it). Over 400 Italian tourism associations and experts are participating in the process involving the "General States of Sustainable Tourism' (October 2015) and the 'General States of the National Tourism Strategic Plan'(April 2016), both held in Naples. Digitalisation has been identified as one of the main challenges to, and opportunities for, a paradigmatic change in Italian tourism (TDLab, 2014). In Italy, the regional level of destination management is the driver of this change as, since in 2001, the national government decentralised both legislative and managerial powers to the regions. Only a few regions have capitalised on Web opportunities to innovate destination management models; most still use traditional destination marketing and promotional methods. In contrast, there is rapid international movement towards innovative Web tools progressing from the Web of Communication (Web 2.0) to the Web of Thought (Web 5.0). Through a multiple case study design focused on four Italian regional/provincial destinations, this contribution aims to provide knowledge on destination value co-creation in the digital world.

\section{Theoretical Background}

\subsection{E-Tourism and the Web of Communication in Destination Marketing}

Both theoretical studies and empirical analyses of a number of different issues connected to the influence of globalisation and ICTs on supply-demand relationships can be extended to the tourism and destination domain. Globalisation has forced changes in market competition - one-dimensionality and physical and administrative borders have all but vanished (Brondoni, 2002) - and has also reshaped the spaces in which multiple tourist actor-to-actor interactions, and the consequent value formation, take place. ICTs have further accelerated these processes, causing a paradigm-shift (Buhalis \& Law, 2008) in the competitiveness of tourism organisations and destinations around the world (UNWTO, 2001), reshaping the role of tourism in affluent societies and newcomer countries 
(Brondoni, 2016) and re-inventing tourist products and experiences. E-tourism has transformed the way in which consumer and experience tourism products are produced and purchased, turning these exchanges into a dynamic co-creation (Gretzel, Fesenmaier, Formica, \& O'Leary, 2006; Neuhofer, Buhalis, \& Ladkin, 2012; Xiang \& Gretzel, 2010; Munar, 2012; Bellini \& Brondoni, 2016). Having taken root in individual consumer space, Web 2.0 and social media are now fostering the transition of conventional strategic marketing, based on power and control (Munar, 2012; Tussyadiah \& Fesenmaier, 2009) and manipulative tourist consumption and production (Ayeh et al., 2012), toward a new marketing paradigm (Wind \& Mahajan, 2002). The emerging digital marketing, in which virtual communities play a significant role, allows to profile consumers (Gnecchi \& Corniani, 2003; Corniani, 2006) and define dynamic co-experiential process approach based on motivational factors (personal cognition and social influence) (Hsu, Ju, Yen, \& Chang 2007). The creation of virtual spaces for stakeholder participation in decision-making processes provides room for e-democracy in destination management and marketing (Sigala \& Marinidis, 2012). Destination management organisations' shift of the locus of power and control to the 'many' capitalises on trust and knowledge sharing between community members to foster destination value co-creation (Munar, 2012; Hays, Page, \& Buhalis, 2013; Cabiddu, Lui, \& Piccoli, 2013; Mariani, Di Felice, \& Mura, 2016). Central to this process are community capacity building (Moscardo, 2008) and the creation of more transparent social intelligence through the networking of various stakeholders via Web 2.0 tools. By empowering and increasing their participation in decision making, this process also fosters democratic destination governance building (Go \& Trunfio, 2011) and joint tourism policy-making formulation and implementation (Ansell \& Gash, 2007; Kooiman, Bavinck, Chuenpagdee, Mahon, \& Pullin, 2008; Beritelli, 2011; Bramwell \& Lane, 2011; Go, Trunfio, \& Della Lucia, 2013; Laws, Richins, Agrusa, \& Scott, 2011; Ruhanen, Scott, Ritchie, \& Tkaczynski, 2010). Operatively, e-democracy covers a range of forms which go from e-information and consultation (weak forms) to e-participation and e-voting (strong forms) (Sigala \& Marinidis, 2012). E-information platforms are passive forms in which stakeholders are informed about, or can give feedback on, destination management organisation decisions. These basic platforms provide contacts and information on a variety of issues, including national and regional laws, tourism and non-tourism statistics, procedures and forms, strategic plans, main tourist cities and resources. When information platforms are comprehensive and integrated and facilitate interactive communication, they become e-consultation platforms, i.e. destination marketing information systems (Wang \& Russo, 2007). The co-creation of tourism experiences is facilitated by key successful Web factors, such as: information quality, ease of use, responsiveness, security/privacy, appearance, trust, interactivity, personalisation, and, fulfilment (Park \& Gretzel, 2007). Finally, eparticipative platforms are social communities where the e-democratic potential of Web 2.0 tools allows tribal dynamics between members to play an active role in destination brand building, participative strategies and experiential product creation. These different forms of e-democracy, while enhancing the progressive delegation to virtual community members of power and control over the generation of content, also register the evolution of digital value co-creation from user 
insourcing (DMO environment and control) to crowdsourcing and community consolidation (community environment/dynamics not controlled by the DMO) (Gyimóthy, Munar, \& Larson, 2014).

\subsection{The Evolving Web}

Rapidly evolving Web tools are transforming the digital world, which is currently shifting from the Web of Communication (Web 2.0) to the Web of Thought (Web 5.0). This evolution increases opportunities for community consolidation and stakeholder engagement in destination management and marketing, while providing enhanced forms of communication for DMOs and immersive virtual experiences for tourists/users (Figure 1). Web 1.0 was the stage of static, read-only websites on which users were not able to communicate with producers of information, which meant that the latter received no feedback. This stage is almost completely over, superseded by the Web of Communication or participative Web (Web 2.0) which, through its focus on community, has enabled users both to contribute and share content. By providing information and stimulating conversation, Web 2.0 shapes decisions in new ways that are cheaper and have a greater reach than traditional marketing tools, thus facilitating travelers' pre-, during and post-trip decision making. These changes have a direct effect on suppliers' segmentation, communication, promotion, distribution and management activities (Leung, Law, van Hoof, \& Buhalis, 2013), enhancing the differentiation of destinations' tourism experiences and the offer of tailor made products. Several commercially available general-purpose software packages (Socialbakers, Fanpage Karma, Followerwonk) provide Web 2.0 analytics which can be used to analyze the engagement of audiences via social platforms, social media in particular. The main metrics concern the size of community, the amount of content generated by users or DMOs (e.g. text, links, video and photos) and the number of visitor interactions generated by content (e.g. like, share and comments in Facebook) along with the response time, how quickly users react to actions or interactions (Socialbakers, 2015). These tools can retrieve, select, extract and elaborate a huge amount of data effectively, but they do not provide a full understanding of contextual information, e.g. visitor sentiment (Schetzina, 2010). The Web of Context (Web 3.0) stage is characterised by computerised applications developed by software companies and researchers (Lai \& To, 2015) in order to understand this contextual information. Computerbased text mining and user interaction sentiment analysis systems code raw text, identify the factor structure (lexical analysis) and interpret this structure (text mining) to assess visitor attitude, sentiment and behavior: how visitors really feel about tourism products, experiences, and destination brands. Versatile methods for the selection, collection, processing and analysis of contextual information have not yet been developed; nevertheless, web services and software systems designed to support computer-to-computer interaction over the Internet represent a further development of the above applications, and allow them to communicate directly and facilitate wider searches for information through more simple interfaces. The Web of Things (Web 4.0) and the Web of Thought (Web 5.0) are the latest stages. Web 4.0 is the adaptation of the Web to the mobile surroundings that connect all devices in the real and virtual world. Web 5.0 represents a real step forward, since 
it involves emotional interaction between humans and computers by allowing the Web to recognize users' emotions and reactions.

We are currently experiencing the coexistence of the Web of Context (Web 3.0) and the Web of Things (Web 4.0). Smart tourism platforms - mobile apps, interactive guides, GeoSpatial tools, action tracking technologies - enhance tourist interactivity in the destination, offer real-time information, facilitate personalised experiences and improve customer service (Buhalis \& Amaranggana, 2014; Della Lucia, 2013). Virtual and augmented reality enhance experiences - before, during and after tourists' visits - in order to build trust in, and loyalty to, the destination. This real-time virtual connection and interaction within and between individuals, objects, and - potentially - emotions, creates challenges and opportunities for destination marketing and requires a 'new digital approach' supported by eMarketing tools that can immerse tourists in interactive experiential space.

Figure 1: From the Web of Content to the Web of Thought

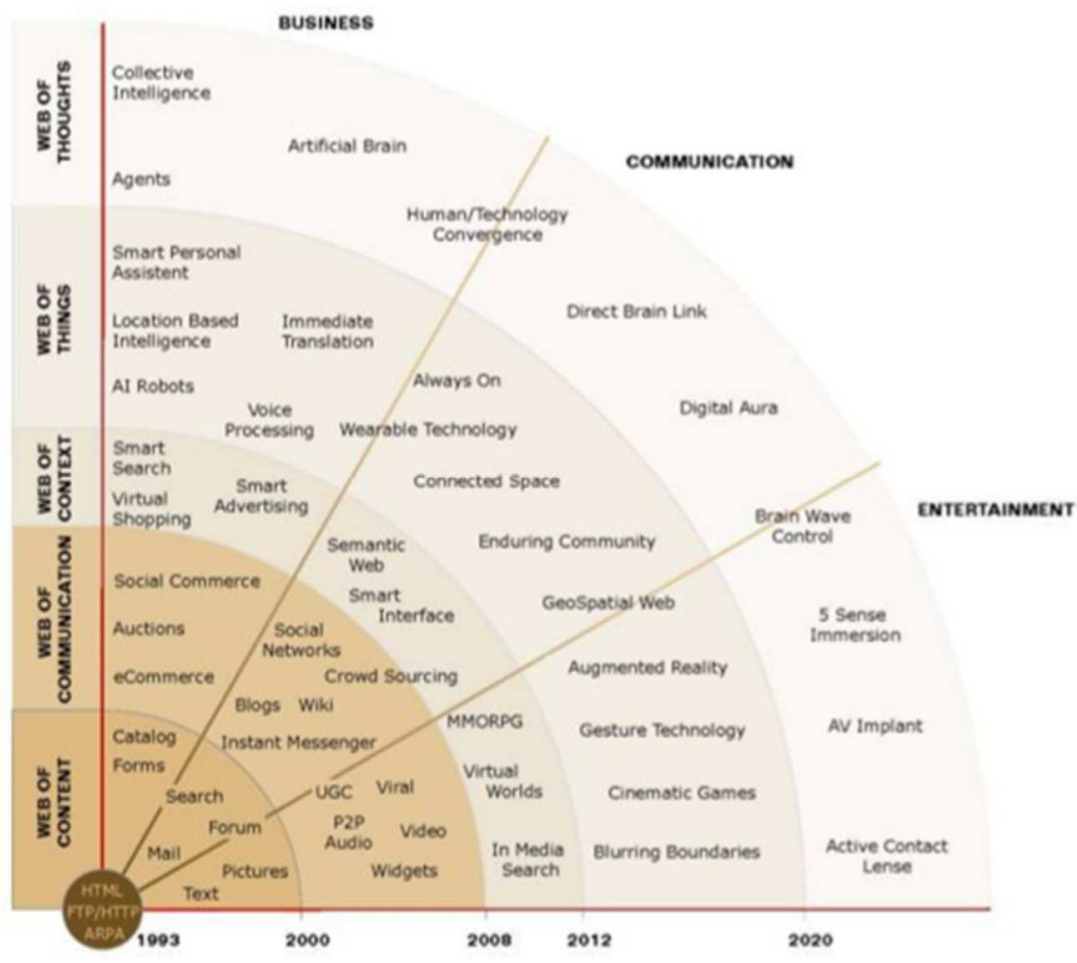

Source: www.TrendONE.de

\section{Case Study: Research Design and Methodological Procedures}

Evolving Web tools (from Web 2.0 to Web 5.0) in destination marketing is examined through an exploratory multiple-case study (Yin, 2014) which focuses on four Italian DMOs. This approach is very effective when the phenomenon being studied is complex and relatively unexplored (Creswell, 2007). The research design is grounded in the most important literature on ICTs and Web use in the field of 
destination management (Buhalis \& Law, 2008; Gyimóthy et al., 2014; Hays et al., 2013; Munar, 2012; Sigala \& Marinidis, 2012) including e-democracy (Sigala \& Marinidis, 2012) and digital community value co-creation (Gyimóthy et al., 2014). These issues are focused on in order to provide preliminary insights into how Italian regional DMOs use innovative Web platforms to enhance e-participation in tourism destination activities, drawing on appropriate sources of case study methodology (Xiao \& Smith, 2006; Baxter \& Jack, 2008).

The regional level (or the provincial, for the Autonomous Provinces of Trentino and South Tyrol) of destination management and marketing analysis is the focus of the analysis: since 2001, the national government decentralised both legislative and managerial powers to the regional/provincial administrative level letting the Italian State Tourist Board been focussed entirely on marketing Italy abroad. This decentralisation process gives the regions the authority to introduce organisational, strategic and technological innovations in destination management and marketing. However, only a handful of regions have used this opportunity to develop distinct regional DMOs to define and coordinate destination management and marketing, whether on or offline. The four DMOs analysed - those of Liguria and Apulia and the provincial DMOs of the two autonomous provinces of Trentino and South Tyrol - are among the six areas whose DMOs are separate from the political-institutional regional/provincial authorities; they have also adopted an innovative approach to destination management and marketing, introducing diverse Web tools to enhance interaction, the co-creation of products and stakeholder engagement. Table 1 lists the DMOs and their main features.

Table 1: Profile of Italian Regional/Provincial DMOs

\begin{tabular}{|c|c|c|c|c|c|c|}
\hline \multirow[b]{2}{*}{$\begin{array}{c}\text { Region/ } \\
\text { Province* }\end{array}$} & \multirow[b]{2}{*}{ DMO } & \multirow[b]{2}{*}{$\begin{array}{l}\text { Legal form (at present) } \\
\text { and Year of constitution }\end{array}$} & \multicolumn{4}{|c|}{ Tourist arrivals in 2015} \\
\hline & & & $\begin{array}{l}\text { No. } \\
\text { (Thousands) }\end{array}$ & $\begin{array}{l}\text { Share } \\
(\%)\end{array}$ & $\begin{array}{l}\text { Regional } \\
\text { Rank }\end{array}$ & $\begin{array}{c}\text { Domestic } \\
\text { share } \\
(\%)\end{array}$ \\
\hline Trentino* & $\begin{array}{l}\text { Trentino } \\
\text { Marketing }\end{array}$ & $\begin{array}{c}\text { Public - Provincial } \\
\text { institution } \\
2015\end{array}$ & 3,498 & 3.3 & 11 th & 59.1 \\
\hline $\begin{array}{l}\text { South } \\
\text { Tyrol* }\end{array}$ & $\begin{array}{c}\text { IDM - } \\
\text { Innovation, } \\
\text { Development } \\
\text { and } \\
\text { Marketing } \\
\text { Südtirol - } \\
\text { Alto Adige }\end{array}$ & $\begin{array}{c}\text { Public - Special } \\
\text { Provincial Agency } \\
2016\end{array}$ & 6,139 & 5.8 & 6 th & 34.0 \\
\hline Liguria & InLiguria & $\begin{array}{c}\text { Public - Regional } \\
\text { institution } \\
1998\end{array}$ & 4,067 & 3.8 & 10th & 55.5 \\
\hline Apulia & $\begin{array}{c}\text { Pugliapromoz } \\
\text { ione }\end{array}$ & $\begin{array}{c}\text { Public - Regional } \\
\text { institution } \\
2011\end{array}$ & 3,271 & 3.1 & 12 th & 79.7 \\
\hline Italy & $\begin{array}{c}\text { Italian State } \\
\text { Tourist } \\
\text { Board }\end{array}$ & $\begin{array}{c}\text { Public - National } \\
\text { institution } \\
2005\end{array}$ & 106,552 & $100 \%$ & $\begin{array}{l}5^{\text {th }} \text { in } \\
\text { the } \\
\text { world }\end{array}$ & $51.5 \%$ \\
\hline
\end{tabular}


The main Web platforms of the four DMOs were examined in order to identify the similarities and differences among them in Web use to market destinations and enhance stakeholder engagement in value co-creation processes. Our data sources were their separate and clearly identifiable corporate websites - devoted to territorial and/or tourism stakeholders - and official tourist websites - used for destination marketing - along with DMO Web platforms and social media. The analysis focused on six DMO social media platforms (Facebook, Twitter, YouTube, Pinterest, Instagram and Google+), chosen because the Strategic Plan for the Digitalisation of Italian Tourism (TDLab, 2014) identifies them as being the most likely to foster the growth of Italian tourism's global digital presence. In addition, the WeAreSocial website (http://wearesocial.com/it/) reported that these platforms were the most widely used in Italy in 2016. YouTube (57\%) and Facebook (55\%) were the most active social media platforms; followed by Instagram (28\%), Twitter (25\%), Google+ (25\%) and Pinterest (15\%).

The two-step collection of case evidence was carried out in April 2016:

1. The identification and classification of the innovativeness of Web tools in destination management and marketing in the different stages of Web evolution:

- Web of communication (Web 2.0): DMOs websites, social media (Facebook, Twitter, Instagram, YouTube, Pinterest and Google+), brand communities and eparticipative platforms;

- Web of things (Web 4.0): smart tourism and augmented reality.

2. The evaluation of social media marketing: social media have become the main Web 2.0 tools used by DMOs when applying Web 3.0 tools (applications connected to destination reporting/decision making). First, the size of the DMO social media communities on each social network (Facebook, Twitter, YouTube, Pinterest, Instagram and Google+) were compared. Then, because it is the most widely used of the social media for destination marketing, each DMO's Facebook performance in potential tourist engagement was analysed. Data on the variables affecting engagement (Socialbackers, 2015) - community size, the amount of content generated by communities/DMOs, the number of visitor interactions generated by content classifiable by type (like, share and comments) and the response rate - were collected in the second week of April 2016 by applying the Fanpage Karma software package.

\section{Results}

The analysis of Web evolution in the four Italian regional and provincial DMOs shows that all these destinations have widely adopted Web 2.0 tools to provide contacts and information on a variety of issues and marketing destination but innovative Web tools - the Web of Things (Web 4.0) (see Table 2 below) - are just emerging. Social media marketing via Facebook (a highly popular Web 2.0 application) plays a crucial role, but performances differ among destinations. 


\subsection{Web Use in Destination Marketing}

The four DMOs have widely adopted Web 2.0 applications that allow both weak and strong forms of stakeholder engagement (Table 2). The four DMOs all use destination marketing information systems like integrated e-consultation platforms to provide comprehensive information and interactive communication spaces on a range of tourism products (Horan \& Frew, 2007; Wang \& Russo, 2007). These platforms are also used to market both independent tourism products and the destination as a whole, i.e. as an integrated product. Interactive virtual communication between stakeholders is enabled on both the demand and supply side: intranets connect networks of tourist actors; dedicated online booking platforms allow e-commerce in the tourism domain; blogs promote innovative tourist products and enhance experiential digital marketing. The Trentino tourist web site (www.visittrentino.it) is a good example of an innovative approach in destination marketing: images, interactions, direct booking etc. build a picture of the diverse tourism experiences that visitors can enjoy in the destination.

The DMOs have also created community spaces which exploit the e-democratic potential of Web 2.0 - social media pages, brand communities and e-participative platforms - thus allowing tribal dynamics to play an active role in destination value co-creation. A web community devoted to brand management has been developed both in Trentino (www.marchiotrentino.it) and South Tyrol (www.provincia.bz.it/marchioombrello/default.asp) to facilitate destination logo use by diverse local tourism firms and organisations (computerised administrative services, information, forms and procedures for the use of the destination and/or quality logo). These Web 2.0 tools all contribute, to varying degrees, to encourage user crowdsourcing, fostering tribal dynamics and harnessing the involvement of stakeholders who share knowledge and experiences and create value.

Liguria and Apulia's web communities (liguria.ilturismochevorrei.it and www.puglia365.it), separate from the official websites, have enhanced the destination marketing information systems and tourism platforms of these regions. In particular, they have encouraged stakeholders (local community; public administrations; institutions; local firms and organisations operating in sectors that complement the tourist offer, like agriculture and manufacturing) to take part in participatory destination strategies and thus create opportunities for community consolidation. Apulia's digital platform (www.puglia365.it) is building a destination strategy for 2016-2025 and involving stakeholders in the debate around six issues - product, promotion, innovation, infrastructure, hospitality and training. The 'My Puglia experience' project engaged young people through a casting process on Facebook and then in itineraries throughout the region. Similarly, the web community of 'Liguria, il turismo che vorrei' (liguria.ilturismochevorrei.it) allows stakeholders to participate in a debate on how the regional tourism can be strengthened.

Innovative Web 4.0 tools are just emerging in the destination marketing of the four DMOs. These destinations have already developed smart tourism platforms which provide mobile solutions to increase tourist access to information, and encourage interactivity to facilitate the creation of personalised experiences (Table 2). In many cases, however, the environment in which these interactions takes place 
is controlled by the DMO, thus minimizing both user-generated content and the participation in experience co-creation. Applications which provide augmented and virtual reality increase integration between tourists and destinations attractions. All the DMOs except South Tyrol have introduced these experimental applications, thus creating immersive spaces that overcome traditional marketing tools: they enhance the destination's image and attractiveness and facilitate travellers' pre-, during and post-trip decision making. The central challenges posed by the Web 4.0 tools are to fully exploit the integration of physical and virtual objects with other user-generated content in order to allow the differentiation of destination tourism experiences and the offer of tailor made products.

Table 2: From Web 2.0 to Web 4.0 in Italian Regional and Provincial Dmos

\begin{tabular}{|c|c|c|c|c|c|}
\hline \multirow[b]{2}{*}{$\begin{array}{l}\text { Region/ } \\
\text { Province* }\end{array}$} & \multicolumn{3}{|c|}{ Web 2.0} & \multicolumn{2}{|c|}{ Web 4.0} \\
\hline & $\begin{array}{c}\text { Destination } \\
\text { marketing } \\
\text { information } \\
\text { system }\end{array}$ & $\begin{array}{l}\text { Social media } \\
\text { platforms }\end{array}$ & $\begin{array}{c}\text { Brand } \\
\text { communities } \\
\text { and } E- \\
\text { participative } \\
\text { platforms }\end{array}$ & Smart tourism & Augmented reality \\
\hline Trentino* & $\begin{array}{l}\text { www.trentinomar } \\
\text { keting.org/it } \\
\text { www.visittrentino } \\
\text {.it }\end{array}$ & $\begin{array}{l}\text { www.facebook.co } \\
\text { m/visittrentino.it } \\
\text { twitter.com/visittre } \\
\text { ntino } \\
\text { www.youtube.com } \\
\text { /user/visittrentino } \\
\text { www.pinterest.com } \\
\text { /visittrentino/ }\end{array}$ & $\frac{\text { www.marchiotrent }}{\underline{\text { ino.it }}}$ & $\begin{array}{l}\text { www.visittrentino } \\
\text { it/it/guida/mobile } \\
\text { www.visittrentino } \\
\text {.it/it/articoli/info- } \\
\text { pratiche/app- } \\
\text { trentino-tourist- } \\
\text { guide }\end{array}$ & $\begin{array}{l}\text { visittrentino.it/it/artic } \\
\text { oli/info- } \\
\text { pratiche/app-around- } \\
\text { trentino }\end{array}$ \\
\hline $\begin{array}{l}\text { South } \\
\text { Tyrol* }\end{array}$ & $\begin{array}{l}\text { www.smg.bz.it } \\
\text { www.suedtirol.inf } \\
\text { o/it }\end{array}$ & $\begin{array}{l}\text { www.facebook.co } \\
\text { m/altoadige.suedtir } \\
\text { ol } \\
\text { twitter.com/visitso } \\
\text { uthtyrol } \\
\text { www.youtube.com } \\
\text { /watch?v=171uCzi } \\
\text { Nfrs } \\
\text { it.pinterest.com/sue } \\
\text { dtirolinfo/ }\end{array}$ & $\begin{array}{l}\text { www.provincia.bz } \\
\text {.it/marchioombrell } \\
\text { o/default.asp } \\
\text { itunes.apple.com/d } \\
\text { e/app/sudtirol- } \\
\text { mobile- } \\
\text { guide/id33901158 } \\
\text { 6?mt=8 }\end{array}$ & $\begin{array}{l}\frac{\text { www.smg.bz.it/it/ }}{\text { marchio-e- }} \\
\text { comunicazione/lal } \\
\text { to-adige- } \\
\text { digitale/applicazio } \\
\underline{\text { ni-alto-adige }}\end{array}$ & \\
\hline Liguria & $\begin{array}{l}\text { www.agenziainlig } \\
\text { uria.it } \\
\text { www.turismoinlig } \\
\text { uria.it }\end{array}$ & $\begin{array}{l}\text { www.facebook.co } \\
\text { m/turismoinliguria/ } \\
\text { twitter.com/Turism } \\
\text { oLiguria?ref_src=t } \\
\text { wsrc^tfw } \\
\text { www.youtube.com } \\
\text { /user/TurismoInLig } \\
\text { uria } \\
\text { www.pinterest.com } \\
\text { /turismoliguria/ }\end{array}$ & $\begin{array}{l}\text { liguria.ilturismoch } \\
\text { evorrei.it }\end{array}$ & $\begin{array}{l}\text { itunes.apple.com/ } \\
\text { it/app/liguria- } \\
\text { laltra- } \\
\text { riviera/id9898259 } \\
53 ? \mathrm{mt}=8 \\
\text { www.beactiveligu } \\
\text { ria.it/it/beactive/a- } \\
\text { piedi.html } \\
\text { itunes.apple.com/i } \\
\text { t/app/liguria- } \\
\text { laltra- } \\
\text { riviera/id9898259 } \\
53 \text { ?mt=8 }\end{array}$ & $\begin{array}{l}\text { www.liguriaheritage. } \\
\text { it/heritage/it/app.do }\end{array}$ \\
\hline Apulia & $\begin{array}{l}\text { www.agenziapugl } \\
\text { iapromozione.it } \\
\text { www.viaggiarein } \\
\text { puglia.it }\end{array}$ & $\begin{array}{l}\text { www.facebook.co } \\
\text { m/viaggiareinpugli } \\
\text { a.it } \\
\text { twitter.com/viaggia } \\
\text { repuglia } \\
\text { www.youtube.com } \\
\text { /user/Viaggiareinp }\end{array}$ & www.puglia365.it/ & $\begin{array}{l}\text { www.viaggiarein } \\
\text { puglia.it/planning/ } \\
\text { it }\end{array}$ & $\begin{array}{l}\text { www.youtube.com/ } \\
\text { watch?v=7K_cD529 } \\
\text { O6M }\end{array}$ \\
\hline
\end{tabular}




\begin{tabular}{|c|c|c|c|c|}
\hline & & $\begin{array}{l}\text { glia } \\
\text { Jww.pinterest.com } \\
\text { viaggiarepuglia/ }\end{array}$ & & \\
\hline Apulia & $\begin{array}{l}\text { www.agenziapugl } \\
\text { iapromozione.it } \\
\text { www.viaggiareinpu } \\
\text { glia.it }\end{array}$ & $\begin{array}{l}\quad \text { www.facebook } \\
\text {.com/viaggiarein } \\
\text { puglia.it } \\
\text { twitter.com/viag } \\
\text { giarepuglia } \\
\text { www.youtube.co } \quad \text { www.puglia365 } \\
\text { m/user/Viaggiare } \\
\text { inpuglia } \\
\text { www.pinterest.co } \\
\text { m/viaggiarepugli } \\
\text { a/ }\end{array}$ & $\begin{array}{l}\text { www.viaggi } \\
\text { areinpuglia.it/ } \\
\text { planning/it }\end{array}$ & $\begin{array}{l}\text { www.youtube.c } \\
\text { om/watch?v=7K_c } \\
\text { D529O6M }\end{array}$ \\
\hline
\end{tabular}

\subsection{Social Media Marketing}

The four Italian DMOs are highly heterogeneous in their use of the six social media platforms (Facebook, Twitter, YouTube, Pinterest, Instagram and Google+). A comparative analysis of the social media shares of DMO communities (Figure 2.a), showed that Facebook is the most widely used DMO social media of the six examined ( $81 \%$ of total social media communities), distantly followed by Twitter $(10 \%)$ and Instagram (6\%); YouTube, Pinterest and Google + have marginal shares (around 1\%). Only the position of Facebook is in line with the WeAreSocial website's ranking of most popular social media in Italy. The Trentino DMO is the best performer in the social media community, ranking first for Twitter, Instagram, Pinterest and Google + followers and second for Facebook fans and YouTube subscribers. South Tyrol ranks highest for Facebook fans and YouTube subscribers, second for Google + followers and last in the other social media communities. Apulia performs a little better than Liguria, ranking second for Twitter and Instagram followers; Liguria ranks second for Pinterest followers (Figure 2.b).

Figure 2: The Social Media Communities of Italian DMOs

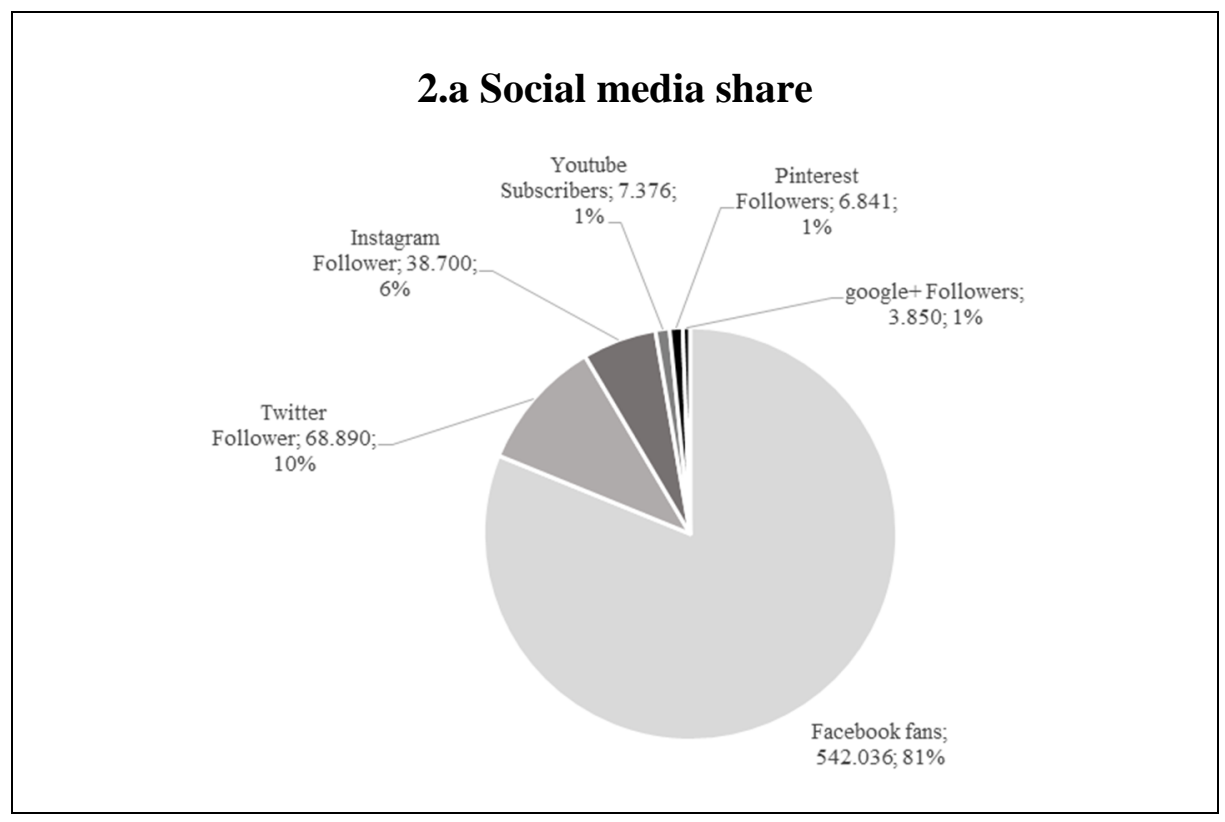




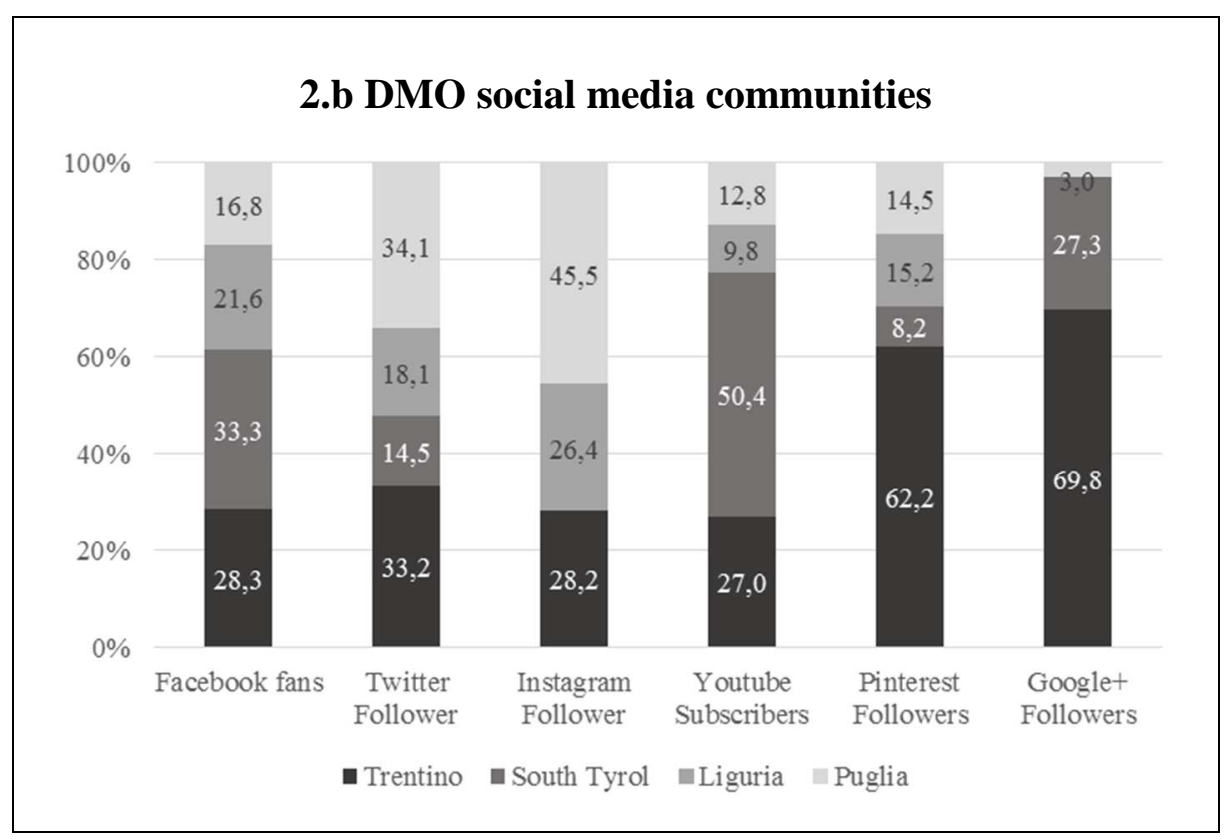

Facebook use, analysed by applying the Fanpage Karma software package, reveals how the DMOs' success in engaging tourists varies (Table 3). The engagement score, which measures the average number of interactions (likes, comments and shares) per fan per day, ranks highest in Trentino, followed by Liguria (1.6) and South Tyrol (1.3); Apulia's fan engagement scores lowest (0.44). Community, content, interactions with content by type (like, comments and share), and response rates contribute differently to these results (Table 3). Trentino's fans, who are part of the second biggest Facebook community, are quite active in producing content - the number of posts per day (3.2) is the second highest after Liguria - but particularly active in reacting to content intensely, promptly $(0.1 \mathrm{~h})$ and with a strong manifestation of interest. South Tyrolean fans (the biggest Facebook community) interact even more intensely than Trentino, with both strong (share) and weak (like) manifestations of interest; however, the amount of content to which they react is the lowest among the DMOs examined and reaction times are very long (16 h). The situations in Liguria and Apulia are completely different. Liguria, which follows Trentino in engagement score, has the third smallest community; although small the community is very active in generating content (4.7 posts per day) and interacting quickly $(2.5 \mathrm{~h})$ and quite intensely to content, and manifests strong interest. Apulia has a very small community which generates little content ( 2.2 posts per day), does not react intensely, generally manifests weak interest, and has long response times $(3.7 \mathrm{~h})$. 
Table 3: DMO Facebook performance. April 2016

\begin{tabular}{l|c|c|ccc|c|cc}
\hline & Community & Content & \multicolumn{3}{|c|}{ Interaction } & \multicolumn{2}{c|}{$\begin{array}{c}\text { Response } \\
\text { rate }\end{array}$} & \multicolumn{2}{|c}{ Fan engagement } \\
$\begin{array}{l}\text { Region/ } \\
\text { Province }\end{array}$ & $\begin{array}{c}\text { Growth } \\
\text { rate }\end{array}$ & $\begin{array}{l}\text { Post } \\
\text { per day }\end{array}$ & $\begin{array}{c}\text { Like } \\
\text { per } \\
\text { post }\end{array}$ & $\begin{array}{c}\text { Comme } \\
\text { nt per } \\
\text { post }\end{array}$ & $\begin{array}{c}\text { Share } \\
\text { per } \\
\text { post }\end{array}$ & Time & $\begin{array}{l}\text { Post } \\
\text { interaction }\end{array}$ & Engagement \\
\hline Trentino* & $0.43 \%$ & 3,2 & 38 & 18 & 98 & $0.1 \mathrm{~h}$ & 0.55 & 1.8 \\
South & $0.50 \%$ & 2,1 & 72 & 23 & 61 & $16 \mathrm{~h}$ & 0.62 & 1.3 \\
Tyrol* & $0.12 \%$ & 4,7 & 7 & 7.3 & 38 & $2.5 \mathrm{~h}$ & 0.35 & 1.6 \\
Liguria & $0.21 \%$ & 2,2 & 53 & 5.5 & 30 & $3.7 \mathrm{~h}$ & 0.20 & 0.44 \\
Apulia & & & & & & & & \\
\hline
\end{tabular}

Fans $=$ Current number of Facebook fans

Growth rate $=$ Average weekly growth of fan numbers in the period of time covered

Posts per day $=$ Average number of texts, photos, videos per day

Like/Share/Comment per post = Average number of likes/comments per post

Response rate $=$ Average time taken to react to fan posts and questions

Post interaction $=$ Average number of likes, comments and shares per fan for all posts

Engagement $=$ Average amount of likes, comments and shares per day, divided by the number of fans

Source: our own elaboration on Fanpage Karma http://www.fanpagekarma.com/

\section{Conclusions}

This paper has explored an under-researched topic in destination management: the exploitation of Web opportunities to market destinations and enhance destination value co-creation through engaging diverse stakeholders in social spaces of communication and knowledge sharing. Levering on the body of destination management literature focused on Web 2.0, it introduces the debate around the Web evolution from 2.0 to 5.0 and analyses the application of innovative destination marketing tools. The empirical evidence shows that that the four Italian DMOs investigated have widely adopted Web 2.0 tools, which allow strong forms of stakeholder engagement in destination marketing, and are implementing Web 3.0 and Web 4.0 tools to support innovative forms of destination marketing. Destination marketing Web 2.0 tools developed in these DMOs - brand communities and e-platforms, smart tourism, augmented and virtual reality apps and platforms - foster virtual tribal dynamics and interactive communication, promote and market destination products, engage tourists in experiential thematic offers, and enhance the reputation of destination brands, thus promoting destination value co-creation. The DMOs of Trentino and South Tyrol lead the way in terms of brand communities, which also encourage place brand building. The digital platforms of Apulia and Liguria are also examples of best practice in how to encourage participatory destination strategy planning. Social media marketing via Facebook (a highly popular Web 2.0 application) plays a crucial role, but performances differ among destinations. Community size theoretically affects the production of content and interactions to content - as Trentino, the best performer, demonstrates. What counts the most, however, is how 
much each fan is active in generating and reacting (quickly) to content, as shown by the small community of Liguria. The lessons learned from this multiple-case study of four Italian DMOs can contribute to the debate on the exploitation of Web opportunities in destination value co-creation processes, and have implications for the reshaping of destination management theory and practice. The technological, market and organisational changes which digitalisation has driven in destination management and marketing also call for participative governance approaches, in which both formal and informal processes entitle diverse stakeholders to share authority and responsibility for the formulation and implementation of destination marketing strategies. These governance mechanisms enable a more effective exploitation of the communication, negotiation and smooth decision-making which occur within a virtual tribal dynamic, and their realisation within participative marketing plans; these processes increase stakeholder engagement by fostering awareness, trust and commitment. Advanced digital marketing systems can thus be expected to have synergetic effects on offline stakeholder engagement and vice versa; passive forms of stakeholder engagement offline risk not capitalizing on the exploitation of Web 2.0 use for e-participation. In Italy, an operative agenda needs to be set in order to enable effective investment in digital platforms aimed at enhancing stakeholder engagement and co-creating tourist products and experiences. The agenda should include the development of web communities to co-create destination strategies and innovative tourist products/experiences; the development and use of software applications to monitor the size of engagement in Web platforms and to detect contextual information (feeling, emotions); the use of this knowledge to re-design destination strategies and tourist experiences; and, finally, the integration of this knowledge with information coming from stakeholder engagement off-line.

\section{Limitations and Future Research}

Further research is needed to overcome the limits of this exploratory study of the shift towards Web 4.0 and Web 5.0. Neuromarketing and ICT applications may be used to retrieve and elaborate data on virtual interactions on different social media platforms, and to compare results. Contextual information, such as the feelings and emotions embedded in conversations, should also be investigated in this regard. The collection of case evidence could be extended to other Italian regions, irrespective of whether or not their DMO is separate from the regional politicalinstitutional authority. Comparisons could also be made with regional DMOs in other countries. Other research might focus on the connection between a DMO's best practices in Web use and the levels of tourist engagement in destination strategic planning.

\section{Bibliography}

Ansell, C., \& Gash, A. (2007). Collaborative governance in theory and practice. Journal of Public Administration Research and Theory, 18(4), 543-571. 
http://dx.doi.org/10.1093/jopart/mum032

Ayeh, J. K., Leung, D., Au, N., \& Law, R. (2012). Perceptions and strategies of hospitality and tourism practitioners on social media: An exploratory study. In M. Fuchs, F. Ricci \& L. Cantoni, (Eds.). Proceedings of the International Conference "Information and Albee, 2010 communication technologies in tourism” (pp. 1-2). Vienna: Springer-Verlag.

Baxter P., \& Jack, S. (2008). Qualitative Case Study Methodology: Study Design and Implementation for Novice Researchers. The Qualitative Report, 13(4): 544-559, Retrieved March, 5, 2015 from http://www.nova.edu/ssss/QR/QR13-4/baxter.pdf.

Della Lucia, M. (2013). Performance measurement systems for event planning and investment decision making. Tourism Management, 34, 91-100.

http://dx.doi.org/10.1016/j.tourman.2012.03.016

Bellini, N., \& Brondoni S. M. (2016). Ouverture de 'Global Tourism in Global Markets', Symphonya. Emerging Issues in Management (symphonya.unimib.it), n. 1, pp. 1-6.

http://dx.doi.org/10.4468/2016.1.010uveture

Beritelli, P. (2011). Cooperation among prominent actors in a tourist destination. Annals of Tourism Research, 38(2), 607-629. http://dx.doi.org/10.1016/j.annals.2010.11.015

Bramwell, B., \& Lane, B. (2011). Critical research on the governance of tourism and sustainability. Journal of Sustainable Tourism, 19(4-5), 411-421.

http://dx.doi.org/10.1080/09669582.2011.580586

Brondoni, S. M. (2002). Global Markets and Market-Space Competition. Symphonya. Emerging Issues in Management (symphonya.unimib.it). n. 1, pp. 28-42.

http://dx.doi.org/10.4468/2002.1.03brondoni

Brondoni, S. M. (2016). Global Tourism Management. Mass, Experience and Sensations Tourism. Symphonya. Emerging Issues in Management (symphonya.unimib.it), n. 1, pp. 7-24.

http://dx.doi.org/10.4468/2016.1.02brondoni

Buhalis, D., \& Amaranggana, A. (2014). Smart Tourism Destinations. In Z. Xiang \& I. Tussyadiah (Eds.), Information and Communication Technologies in Tourism 2014 (pp. 553-564). Springer International Publishing Switzerland.

Buhalis, D., \& Law, R. (2008). Progress in tourism management: 20 years on and 10 years after the internet: The state of eTourism research. Tourism Management, 29(4), 609-623.

http://dx.doi.org/ 10.1016/j.tourman.2008.01.005

Cabiddu, F., De Carlo, M., \& Piccoli, G. (2014). Social media affordances: Enabling customer engagement. Annals of Tourism Research, 48, 175-192.

http://dx.doi.org/10.1016/j.annals.2014.06.003

Cabiddu, F., Lui T. W., \& Piccoli G. (2013). Managing Value Co-Creation in the Tourism Industry. Annals of Tourism Research, 42, 86-107.

http://dx.doi.org/10.1016/j.annals.2013.01.001

Chen, S., \& Choi, C.J. (2004). Creating a knowledge-based city: the example of Hsinchu Science Park. Journal of Knowledge Management, 8(5), 73-82.

http://dx.doi.org/10.1108/13673270410558792

Corniani, M. (2006). Digital Marketing Communication. Symphonya. Emerging Issues in Management (symphonya.unimib.it), n. 2, pp. 41-61.

http://dx.doi.org/10.4468/2006.2.04corniani

Creswell, J. (2007). Qualitative Inquiry and Research Design: Chosing Among Five Approaches. Thousand Oaks: Sage Publications.

Funilkul, S., \& Chutimaskul, W. (2009). The framework for sustainable eDemocracy development. Transforming Government: People, Process and Policy, 3(1), 16-31.

http://dx.doi.org/10.1108/17506160910940713 
Gnecchi F., \& Corniani M. (2003). Demand Bubbles, Virtual Communities and Market Potential, Symphonya. Emerging Issues in Management (symphonya.unimib.it), 2, 34-50.

http://dx.doi.org/10.4468/2003.2.04gnecchi.corniani

Go, F.M., \& Trunfio, M. (2011). E-Services Governance in public and private sector: a Destination Management Organization Perspective. In A. D'Atri, M. Ferrara \& J.F. George (Eds.), Information Technology and Innovation Trends in Organizations (pp. 10-19). Vienna: SpringerVerlag.

Go, F.M., Trunfio, M., \& Della Lucia (2013). Social capital and governance for sustainable rural development. Studies in Agricultural Economics, 115 (2), 104-110.

http://dx.doi.org/10.7896/j.1220

Gretzel, U., Fesenmaier, D.R., Formica, S., \& O'Leary, J.T. (2006). Searching for the future: Challenges faced by destination marketing organizations. Journal of Travel Research, 45(4), 116126.

http://dx.doi.org/10.1177/0047287506291598

Gyimóthy, S., Munar, A. M., \& Larson, M. (2014). Consolidating Social Media Strategies. In L.D.A.N. Dioko (Ed.), Proceedings of the 5th International Conference of Destination Branding and Marketing (DBM-V) (pp. 154-168). Macao: Institute for Tourism Studies.

Hays, S., Page, S., \& Buhalis, D. (2013). Social media as a destination marketing tool: its use by national tourism organizations. Current Issues in Tourism, 16(3), 211-239.

http://dx.doi.org/10.1080/13683500.2012.662215

Hsu, M.H., Ju, T.L., Yen, C.H., \& Chang, C.M. (2007). Knowledge sharing behavior in virtual communities: The relationship between trust, self-efficacy, and outcome expectations. International Journal of Human Computer Studies, 65, 153-169.

http://dx.doi.org/10.1016/j.ijhcs.2006.09.003

Kooiman, J., Bavinck, M., Chuenpagdee, R., Mahon, R., \& Pullin, R. (2008). Interactive Governance and Governability: An Introduction. The Journal of Transdisciplinary Environmental Studies, 7(1), 1-11.

Lai, L.S.L., \& To, W.M. (2015). Social Media Content Analysis: A Grounded Approach. Journal of Electronic Commerce Research, 16(2), 138-152.

Laws, E., Richins, H., Agrusa, J., \& Scott, N. (2011). Tourist Destination Governance. Cambridge: CABI.

Leung, D., Law, R., van Hoof, H., \& Buhalis, D. (2013). Social Media in Tourism and Hospitality: A Literature Review. Journal of Travel \& Tourism Marketing, 30(1-2), 3-22.

http://dx.doi.org/10.1080/10548408.2013.750919

Luo, X., Zhang, J., \& Duan, W. (2013). Social Media and Firm Equity Value. Information Systems Research, 24(1), 146-163. http://dx.doi.org/10.1287/isre.1120.0462

Mariani, M., Di Felice, M., \& Mura, M. (2016). Facebook as a destination marketing tool: Evidence from Italian regional Destination Management Organizations. Tourism Management, 54, 321343.

http://dx.doi.org/10.1016/j.tourman.2015.12.008

Munar, A.M. (2012). Social Media Strategies and Destination Management. Scandinavian Journal of Hospitality and Tourism, 12(2), 101-120. http://dx.doi.org/10.1080/15022250.2012.679047

Neuhofer, B., Buhalis, D., \& Ladkin, A. (2012). Conceptualising technology enhanced destination experiences. Journal of Destination Marketing \& Management, 1, 36-46. doi: 10.1016/j.jdmm.2012.08.001

Park, Y.A, Gretzel U. (2007). Success factors for destination marketing web sites: A qualitative meta-analysis. Journal of Travel Research, 46(1), 46-63. http://dx.doi.org/10.1177/0047287507302381 
Pechlaner, H., Herntrei, M., Pichler, S., \& Volgger, M. (2012). From destination management towards governance of regional innovation systems - the case of South Tyrol, Italy'. Tourism Review, 67(2), 22-33. http://dx.doi.org/10.1108/16605371211236123

Racherla, P., Hu, C., \& Hyun, M.Y. (2008). Exploring the role of innovative technologies in building a knowledge-based destination. Current Issues in Tourism, 11(5), 407-428. http://dx.doi.org/10.1080/13683500802316022

Rifkin, J. (2011). The Third Industrial Revolution. How Lateral Power Is Trans-forming Energy, the Economy, and the World. New York, NY: Palgrave MacMillan.

Ruhanen, L., Scott, N., Ritchie, B., \& Tkaczynski, A. (2010). Governance: a review and synthesis of the literature. Tourism Review, 65(4), 4-16.

http://dx.doi.org/10.1108/16605371011093836

Schetzina, C. (2010). Introduction to social media analytics. New York, NY: PhoCusWright.

Sigala, M., \& Marinidis, D. (2012). E-Democracy and Web 2.0: A Framework Enabling DMOs to Engage Stakeholders in Collaborative Destination Management. Tourism Analysis, 17(2), 105120. https://doi.org/10.3727/108354212X13330406124052

Socialbakers (2015). Social bakers analytics. User guide. Available online at: http://analytics.socialbakers.com/template/classic/media/SocialbakersAnalyticsGuide.pdf.

TDLab (2014). Strategic Plan for Digitalization of Italian Tourism. Roma: Ministry of Culture and Tourism.

Trunfio, M., Go, F.M., \& Ferretti, M. (2012). Disruptive Innovation by Smarter Destination Platform Knowledge Diffusion: Towards a Theory of Demand and Supply Governance. In A. Morvillo (Ed.), Competition and Innovation in Tourism: New Challenges in an Uncertain Environment (pp. 461-480). Napoli: Enzo Albano Editore.

Tussyadiah, I.P., \& Fesenmaier, D.R. (2009). Mediating Tourists Experiences-Access to Places via Shared Videos. Annals of Tourism Research, 36(1), 24-40.

http://dx.doi.org/10.1016/j.annals.2008.10.001

UNWTO, (2001), eBusiness for Tourism: Practical; guidelines for destinations and businesses, Madrid: World Tourism Organisation.

UNWTO (2016). Tourism highlights (2016 Edition). Madrid: World Tourism Organisation.

Wang, Y., \& Russo, S.M. (2007). Conceptualizing and evaluating the functions of destination marketing systems, Journal of Vacation Marketing, 13(3), 187-203. http://dx.doi.org/10.1177/1356766707077687

Wind J., Mahajan V. (2002). Digital Marketing. Symphonya. Emerging Issues in Management (symphonya.unimib.it), n. 1, pp. 43-54.

http://dx.doi.org/10.4468/2002.1.04wind.mahajan

WTTC (2016). Travel \& Tourism economic impact 2016. Italy. London: WTTC.

Xiang, Z., \& Gretzel, U. (2010). Role of social media in online travel information search. Tourism Management, 31(2), 179-188.

http://dx.doi.org/10.1016/j.tourman.2009.02.016

Xiao, H., \& Smith S.L.J. (2006). Case studies in tourism research: A state-of-the-art analysis. Tourism Management, 27, 738-749.

https://dx.doi.org/10.1016/j.tourman.2005.11.002

Yin, R.K. (2014). Case study research: Design and methods (5 ed.). Thousand Oaks, CA: Sage Publications. 